\title{
A TALE OF THREE CITIES: ELECTORAL ACCOUNTABILITY IN INDONESIAN LOCAL POLITICS
}

\section{Diego Fossati}

Griffith Asia Institute and Centre for Governance and Public Policy, Griffith University 170 Kessels Road, N16 Room 1.75, Nathan QLD 4111, Australia

Email: d.fossati@griffith.edu.au

Local politics is a key arena for political participation, and policies implemented by local government can shape a variety of political and social outcomes, ranging from access to social services to infrastructure development, environmental protection, human rights, and many others. Patterns of local democratic accountability, however, often display dramatic sub-national variation, especially in diverse young democracies where spatial inequalities are stark. While some local governments are responsive to the preferences of their constituents, others become prey to powerful local elites who avail themselves of democratic institutions to further consolidate economic and political domination.

Indonesian local politics is an apt illustration of such subnational variation in political processes and policy outcomes. The decentralisation laws implemented in the early 2000s have provided Indonesian districts and provinces with unprecedented financial resources, establishing a legal basis for local government activism in a wide range of policy areas. In many respects, however, the outcomes of decentralisation in Indonesia are often described as disappointing, and wide subnational inequalities persist in various indicators of social development (see Lewis 2014).

Scholarly research has long acknowledged serious flaws in how democracy works in Indonesian regions, focusing on local politics as a crucial determinant of local policy outcomes. Work by Hadiz (2004a, 2004b; 2010), for instance, has amply documented enduring elite entrenchment in local government, exposing how patterns of oligarchic rule prevent meaningful 
political change. Other scholars have qualified this critical view, showing that increased civil liberties have allowed the emergence of more assertive actors pushing a reformist agenda, and that elected politicians are not insulated from the pressures of bottom-up political agency (Davidson 2007; Mietzner 2013; Aspinall 2013). Yet most studies of Indonesian local politics suggest that genuine democratic accountability is often lacking due to various issues that typically plague democratic consolidation in young democracies, such as widespread corruption, the dominance of powerful patronage networks, and ethno-religious polarisation (Mietzner 2011; Aspinall, Dettman, and Warburton 2011). These findings resonate with studies of national politics showing the pervasiveness of clientelist linkages between voters and politicians and the inadequacy of political parties to provide meaningful choices for voters (Aspinall and Sukmajati 2016; Slater 2004).

We do not question that local democracy in Indonesia presents important limitations. For many Indonesians, local politics is synonym with "money politics," patronage networks are crucial channels to navigate local government, and purely materialist considerations are a powerful driver of political behaviour. Nevertheless, linkages between voters and politicians are more complex than typically assumed in the literature, and clientelism is far from being the only mode of accountability. For instance, a recent study of clientelist exchanges in Java shows that, while the incidence of vote-buying is high, there is little evidence that monetary incentives are the main factor shaping voting behaviour (Aspinall Rohman, Hamdi, and Triantini. 2017, 21). This suggests that undesirable practices such as corruption and vote-buying can co-exist with other, more palatable forms of citizen-politician linkages, such as voting based on programmatic factors. However, as most scholarly work has focused on the specificities and the aberrations of local democracy in Indonesia, some questions that have been widely investigated in the 
comparative literature on democratic accountability and voting behaviour remain unanswered. How do Indonesian voters evaluate the performance of local politicians and local government? Do such evaluations affect electoral outcomes? And if so, under what circumstances?

To address these questions, we follow an unconventional approach to the study of Indonesian local politics by drawing from the comparative literature on "retrospective voting" (see Healy and Malhotra 2013). In this framework, accountability is studied through the analysis of voting behaviour and public opinion surveys where voters use information from various sources to evaluate politicians for their performance on issues such as managing the economy and providing public safety, and such evaluations inform their electoral choices. ${ }^{1} \mathrm{We}$ hypothesise that Indonesians, to a certain degree, cast their votes in local elections based on their evaluations of the performance of elected politicians, being more likely to vote for incumbent leaders when they are satisfied with how local government works. We further argue, however, following research on retrospective voting in young democracies, that a host of institutional and individual-level factors play an important role as moderators of the link between perceived local government performance and support for the incumbent (Duch 2001). As a result, the strength and the extent of retrospective voting in Indonesian local politics varies considerably both across localities and voters. At the institutional level, voters are more likely to vote retrospectively in

${ }^{1}$ While democratic accountability entails various forms of participation and interaction between citizens and politicians, we focus here on accountability through formal electoral channels. Throughout the article, we rely on public perceptions as measures of government performance rather than on macro-level indicators such as policy outcomes. This approach permits the study of individual-level voting behavior. 
regions with robust democratic institutions and high levels of civic engagement. At the individual level, retrospective voting is more prevalent in voters who trust the integrity of local electoral institutions, are better informed about local politics, and believe local government to be responsible for the condition of their city.

We test these hypotheses with an analysis of three surveys implemented in the cities of Medan in North Sumatra, Samarinda in East Kalimantan, and Surabaya in East Java shortly after mayoral elections on December 9, 2015. As mentioned, we apply a theoretical framework that, although dominant in the comparative literature on voting behaviour, is novel for Indonesia. In studying democratic accountability as retrospective voting, we can determine if, and to what extent, the performance of elected politicians shapes electoral outcomes, as it does in other democracies. Second, in comparing three cities that vary dramatically in local politics, we document substantial variation in electoral behaviour patterns in Indonesian regions. This confirms a widely accepted finding on Indonesian politics, namely that local politics presents stark sub-national variation, and we show that this variation is associated with specific patterns of voting behaviour; this is a notion that has not been empirically tested in existing research. Finally, we use survey data to provide the first comparative study of individual-level voting behaviour in Indonesian local politics and, to the best of our knowledge, the first study of this kind for local elections in any young democracy. By focusing on ordinary Indonesians rather than powerful political elites and their networks, we emphasise the agency of common voters, a heterogeneous but important political force whose role in local politics is often neglected. By applying the retrospective voting framework, we can assess why ordinary voters vary in their ability and willingness to keep local politicians accountable. Overall, our analysis indicates that accountability in Indonesian local politics may assume forms that are distinct from, although not 
necessarily exclusive of, clientelist linkages. Like voters elsewhere in the world, Indonesians can and do hold their local leaders accountable through their vote, which suggests that the process of democratic consolidation in Indonesian regions may be more advanced than is often suggested.

The remainder of the article proceeds as follows. After a brief review of the literature on Indonesian local politics, we develop our framework by building on work about retrospective voting. Following this, we introduce our three field sites and the research design. We then present the results of quantitative analysis and we conclude by discussing the implications of our findings and commenting on directions for further research.

\section{LOCAL DEMOCRACY IN INDONESIA}

A distinctive feature of democratisation in Indonesia is that it was coupled with the implementation of sweeping decentralisation reforms. Decentralisation laws, approved in 1999 and implemented in 2001, have channelled unprecedented financial resources toward local governments, granting them powers in areas such as infrastructure, healthcare, education, trade and industry, human resources, environmental protection, agriculture, and the management of natural resources (Seymour and Turner 2002, 38). Today, Indonesia is a substantially decentralised country, divided into 34 provinces and 508 local governments, in which various levels of government share power in key policy areas. Since 2005, Indonesians have chosen their local leaders, namely mayors, district heads (bupati) and province governors, through local direct elections, known as pemilihan kepala daerah or pilkada.

Such far-reaching institutional changes, at least in principle, create new opportunities for democratic accountability, as suggested in the literature on fiscal federalism (Tiebout 1956; 
Oates 1999). By empowering local government with new prerogatives, decentralisation allows the implementation of policies that more closely mirror local preferences; by empowering citizens with direct elections, it allows people to vote out of office politicians who do not perform adequately. The outcomes of decentralisation in Indonesia, however, suggest that such reforms have failed to substantially advance democratic accountability and development. In some cases, regional autonomy has indeed enabled local government to promote a reformist agenda by implementing policies that have benefited large segments of society, including the most vulnerable (see Fossati 2017; Rosser and Wilson 2012; Leisher and Nachuk 2006). However, there is little evidence of a systematically positive effect of decentralisation reforms on the delivery of social services (Schulze and Sjahrir 2014). Poverty reduction has proceeded at a pace no faster than the under centralised authoritarianism of the Soeharto regime (Ilmma and Wai-Poi 2014). Furthermore, decentralisation has featured dramatic sub-national variation in local-level government expenditure patterns and progress in alleviating poverty (Sumarto, Vothknecht, and Wijaya 2014; Lewis, McCulloch, and Sacks 2014).

To be sure, these sub-national inequalities are nothing new in Indonesia, an exceptionally diverse country where regions have long varied in geography, social and economic history and local government practices. Yet a large literature suggests that local politics in post-authoritarian Indonesia has played a key role in consolidating sub-national inequalities. In many regions, decentralised democracy has been derailed by powerful local elites who have hijacked local government to advance their predatory interests (see Hadiz 2010). In these cases, politics features strong continuities with the authoritarian era of the New Order, including widespread corruption, intimidation, violence, and a lack of genuine political competition (Hadiz and Robison 2005; Buehler 2010). As elsewhere in decentralised developing countries, local politics 
is thus a key determinant of social welfare in Indonesia (Bardhan 2002). Factors such as electoral competitiveness, informal dynamics of accountability, and the nature of the coalitions supporting local leaders are crucial in fostering desirable local-level policy outcomes (Pepinsky and Wihardja 2011; Von Luebke, McCulloch, and Patunru 2009; Tans 2012).

The contribution of pilkada elections to democratic consolidation is still a matter of debate. On one hand, popular support for direct elections is exceptionally high. A survey carried out in 2014 by the Lembaga Survei Indonesia estimates support for direct elections at local leaders at $84.1 \%$ of the population, showing that pilkada elections are strongly preferred to the previous electoral system, in which local leaders were indirectly elected by local representative councils (LSI 2014). On the other hand, scholarly research has exposed flaws associated with pilkada elections. Evidence from various regions indicates that local direct elections, while they may have increased the bargaining power of voters vis-à-vis local political elites, have typically failed to mark a dramatic discontinuity in local government, and scholars have often analysed pilkada to document the various pitfalls of "low-quality democracy" (Van Klinken 2009; Mietzner 2009). Rather than being based on programmatic competition, pilkada elections often feature corruption and the entrenchment of political dynasties, questionable financing practices, ethnic and religious divisions, the dominance of personal and patronage networks, and weak political parties (see, for example, Aspinall et al. 2011; Mietzner 2011; Simandjuntak 2012; Buehler 2013). This suggests that the outcomes of the introduction of local elections are not unconditionally positive. Rather, as for decentralisation reforms, the effect of national institutional change has been contingent on the specific configuration on local politics in Indonesian regions (Choi 2007; Fossati 2016a). 
The extensive literature on local-level politics has significantly advanced our understanding of Indonesian politics, showing how power dynamics at the local level have persisted, adapted and evolved in the era of decentralised democracy. However, this literature has two important limitations. The first is that it focuses overwhelmingly on political elites, as it typically features in-depth analyses of candidates and their relations with political parties, consultants, brokers and key local power-holders such as business groups and religious organisations. As a result, while we know a lot about how elites compete, collude and mobilise consensus to win elections and maintain power, we know much less about how ordinary voters experience these political dynamics, how they evaluate politicians, and whether, if at all, such evaluations affect their voting behaviour. Second, patronage politics has been the dominant approach to study democratic accountability in Indonesian local politics. While is it clear that clientelist linkages based on ethnicity, region or partisanship loom large in Indonesian politics, we emphasise that clientelism is only one of the many forms of democratic accountability in local politics. We hypothesise that many voters, when participating in local elections, choose whether to support incumbent politicians based on how well they did while in office. In other words, instead of focusing on how the Indonesian case deviates from an ideal-type of democratic accountability in which voters choose according to programmatic factors and the performance of elected politicians, we ask to what extent Indonesian local politics conforms to this model.

To answer this question, we turn to the comparative literature on voting behaviour, which conceptualises democratic accountability as a process in which citizens vote according to their perceptions of the past performance of incumbent politicians. In studying Indonesian local politics through these lenses, we can investigate if democratic accountability may unfold along 
patterns that differ from those typically highlighted in the literature, such as clientelism and ethnic politics.

\section{RETROSPECTIVE VOTING AND LOCAL GOVERNANCE: THE INSTITUTIONAL DIMENSION}

Political scientists have devoted substantial attention to studying if, and to what extent, voters keep elected politicians accountable for their performance. The extensive literature on retrospective voting has shown that, in a wide range of empirical settings, support for incumbent politicians is associated with voters' evaluations of their performance, and in particular of their success in managing the economy (Healy and Malhotra 2013; Anderson 2007). While the theoretical frameworks employed to account for this empirical association vary, a recurring assumption is that voters have a set of common preferences over a host of issues, such as boosting economic growth, fighting corruption, and increasing public safety, and that they choose whether to confirm incumbent politicians based, at least in part, on their performance in these areas. This mechanism of electoral accountability is theorised as being key in fostering good government, as it is considered to motivate virtuous behaviour among politicians and, in the long run, it increases the quality of elected politicians.

As local governments, in many political systems, are endowed with considerable policy powers, we may expect voters in local elections to reward or punish local politicians for their performance while in office. Most scholarly work on retrospective voting, however, has ignored local politics. According to a survey of the literature by Berry and Howell (2007, 845), only 1\% of published work on retrospective voting focused on local elections, and scholars have referred 
to local elections as the "perennial bridesmaids" or the "poor cousin” of voting behaviour research (Kaufmann and Rodriguez 2011, 101; Cutler and Matthews 2005, 359). One of the reasons of this neglect is that local politics are considered as substantially different from national politics Local elections typically feature lower levels of information and participation than higher-order competitions, and they are often dominated by candidate personality and race, as confirmed in some early empirical studies of retrospective voting in American local government (Kaufmann 2004; Oliver and Ha 2007).

Despite these difficult beginnings, a small literature on retrospective voting in local government elections has developed. This work, mostly focused on the United States, shows that support for local politicians is affected by evaluations of local government, both general and pertaining to specific policy areas such as education, infrastructure, and management of the local economy (Berry and Howell 2007; Hopkins and Pettingill 2015; Howell and Perry 2004). As this nascent literature focuses exclusively on a small set of rich countries with consolidated democracies, we do not know if the findings extend to young democracies and local government in low and middle-income countries. However, one key feature of governance in decentralised young democracies invites caution in extrapolating these findings. In large and diverse countries such as Indonesia, sub-national variation in local institution can be extreme and the comparative literature has demonstrated that institutional factors are crucial in shaping the process through which voters attribute responsibility for policy outcomes (Powell and Whitten 1993; Duch and Stevenson 2008).

Two features of local politics in young democracies, in particular, deserve scrutiny. First, when local politics is dominated by clientelism or identity-related factors such as ethnicity and religion, as it is the case in many Indonesian regions, voters may be more concerned about 
receiving selective benefits than rewarding or punishing incumbents for their performance (Keefer 2007; Keefer and Khemani 2005). Second, problems of political selection are often exacerbated by low levels of political competition and information. When most elected politicians are perceived as being dishonest, voters may conclude that all politicians are, and that discriminating among politicians based on their performance is not worth the effort (Svolik 2013). This creates a vicious circle of political apathy, poor leadership and mismanagement of the public sector. We thus hypothesise that, where civic engagement is high, citizens satisfied with local politics and trustful of government institutions, voters are more likely to keep local politicians accountable by voting retrospectively. By contrast, where local politics is characterised by corruption, ethnic polarisation, and a lack of political participation, evaluations of performance are less likely to be linked to voting behaviour.

\section{MICRO-LEVEL HETEROGENEITY IN LOCAL-ELECTION RETROSPECTIVE VOTING}

Several studies on retrospective voting have focused on heterogeneity among voters. In a seminal article, Duch (2001) identifies two sources of heterogeneity in voting behaviour in newly established democracies, the first being information. A key assumption of retrospective voting studies is that citizens are informed about politics: in the absence of sufficient levels of information in the electorate, voters fail to monitor the performance of elected politicians. Information and cognitive sophistication are thus important factors shaping retrospective voting, and research on this subject suggests that knowledgeable voters are more likely to base their voting choices on incumbent performance (Gomez \& Wilson, 2001) This view may extend to 
local-election voting behaviour in low and middle-income countries such as Indonesia.. In fact, the role of information may be particularly important in young democracies, where voters may be less aware of the demands that democratic accountability places upon them and less familiar with processing information from multiple sources of political news (Duch 2001, 897). We should therefore expect better-informed voters to be more likely to engage in retrospective voting.

Second, Duch (2001) found that retrospective voting is stronger in individuals with higher levels of trust in political actors and government institutions. Duch argues that trust affects evaluations of incumbent politicians and the electoral process. When voters trust that government works efficiently and takes correct decisions, they tend to believe that incumbent politicians can be controlled through the threat of electoral defeat. When incumbents perform poorly, high-trust individuals are more likely to believe that replacing them with challengers may lead to the implementation of better policies. By contrast, low-trust voters typically consider elections as contests in which rent-seekers prevail, and they often do not see a substantial difference between incumbents and their challengers.

Recent work has adopted a similar approach to study in greater detail the role of trust in electoral institutions, showing that low levels of trust in the integrity of elections depress voter turnout (see Martinez i Coma and Trinh 2017; Simpser 2012; Birch 2010). When voters believe that the electoral process is unfair, they feel their vote is not sufficiently "meaningful” and they are less likely to participate in the political process (Birch 2010). The logic we hypothesise for local retrospective voting in Indonesia, where local elections are often plagued with fraud, violence and irregularities, is similar. Voting retrospectively demands substantial effort from voters and a belief that voting matters is an essential prerequisite for this process. Low trust in 
electoral institutions breeds political apathy and disengagement by making voters feel defrauded and disenfranchised. In voters with no faith in the electoral process, political participation, either in the form of retrospective voting or voting tout court, is less likely.

Work on voting behaviour in decentralised political systems has identified a third factor shaping retrospective voting in local elections: the process through which voters attribute responsibility for policy outcomes. In research on economic voting in federalist countries, where policy prerogatives are dispersed across multiple levels of government, voters often struggle to attribute responsibility, and retrospective voting may thus not occur (Anderson 2006; Cutler 2004; Leon 2011). The process of responsibility attribution may thus be important in localelection voting behaviour in Indonesia, a multi-level political system with overlapping policy jurisdictions in many policy areas.

To be explicit, we expect that retrospective voting is stronger in voters who are politically knowledgeable, trust the integrity of local electoral institutions and believe local government to be responsible for local policy outcomes.

\section{RESEARCH DESIGN: THE THREE FIELD SITES}

The research design for this article follows a two-pronged approach that allows an analysis of macro- and micro-level variation in voting behaviour patterns. The empirical test for the first hypothesis about local institutions is based on a comparison among three Indonesian cities (Medan, Samarinda and Surabaya) that vary substantially in practices of governance and local democracy, as shown in Table 1. Medan, the capital of North Sumatra and third largest city in Indonesia, is a typical case of a dysfunctional local democracy, as politics in this city has a 
tradition of ethno-religious polarisation, corruption and intimidation (Aspinall, Dettman, and Warburton 2011; Hadiz 2006, 93). The last mayoral elections in late 2015, preceded by a series of corruption scandals involving high-ranking local and provincial government officials, marked a negative record in electoral participation with a turnout of $24.9 \%$, the lowest in Indonesia. Such widespread disaffection with local politics is closely related to other indicators reported in Table 1 , such as low levels of political interest and information, high dissatisfaction with local government performance and candidates at local elections and a relatively high share of respondents thinking local elections are not free and fair. Citizens of Medan are much more likely than Samarindans and Surabayans to mention corruption as a key problem, and experts agree that politics in this city is highly transactional.

\section{INSERT TABLE 1 ABOUT HERE}

Tracing the roots of such dysfunctionality is challenging, but colonial history in this region is an important factor to explain contemporary distrust in government institutions. East Sumatra, the region including today's Medan, was a frontier territory for European colonisers, who considered it an inhospitable land sparsely populated by primitive, unreliable people (Reid 2014, 38-42). This view had two important implications for state-building and social development. First, it encouraged large-scale deployment of brutal, highly exploitative production methods in the local plantation economy, resulting in extreme inequality and exceptionally high levels of conflict between labourers and European settlers. Second, it inspired policies to attract contract labourers from outside the region, mostly from China and Java. Such migration altered the ethnic 
composition of the region, exacerbating ethnic conflict. ${ }^{2}$ Factors such as harsh state repression, stark inequality and ethnoreligious tensions have thus featured in the history of this region for decades, and they have taken a toll on civic life in its capital city.

In sharp contrast with Medan, Surabaya in East Java is often described as a success story of decentralisation (see Bunnell, Miller, Phelps, and Taylor 2013). Its mayor, Tri Rismaharini, is one of the most popular politicians in the country, and her success in managing Indonesia's second largest city is widely recognised, as the high scores of perceived local government performance in Table 1 show. Surabaya is the city with the third lowest clientelism perception score of the 54 local governments for which the index is available, and levels of political information and electoral participation are substantially higher than in Medan. As for trust in local elections, Surabayans perceive overall higher degrees of integrity in local electoral institutions when compared with citizens in Medan or Samarinda, although there is variation across indicators.

Surabaya’s history offers a contrast with that of Medan. While Medan and East Sumatra were a frontier, Surabaya was by the 1880s an important centre of commerce in Southeast Asia, and by the early $20^{\text {th }}$ century it developed into the leading industrial centre in the Netherlands Indies (Dick 2003, 264-5). While Europeans in East Sumatra ruled by violence and directly ran their plantations as “open prisons,” East Java was managed by the Dutch East India Company with a system of indirect rule in which established traditional leaders were gradually

${ }^{2}$ Ethnic divisions are compounded by religious cleavages. While the Javanese, the Malay and other groups are exclusively Muslims, the Batak are predominantly Christian, and most of the Chinese follow Buddhism. 
incorporated into the state structure (Furnivall 2010, 31-7). Where Medan and its hinterland were ripe with ethnic tensions, the population of Surabaya was homogenous in their religion (Islam) and ethnicity (Javanese). Most importantly, Surabaya, commonly referred to as the "city of heroes" for its outstanding contribution to the national independence struggle, boasts a solid and long tradition of civic engagement (Ingleson 2008; Anderson 1972, 126).

Samarinda in East Borneo shows in data reported in Table 1 that its politics falls between those represented by Medan and Surabaya. On one hand, this city, despite being the capital of a region notorious for its corruption, fuelled by the exploitation of rich natural resources such as coal, oil and timber, displays lower levels of corruption than the other two field sites, and indicators of civic engagement and political information are as high, and in some cases higher, than in Surabaya. Furthermore, in contrast with Medan, positive evaluations of local government performance prevail in the survey sample. On the other hand, Samarindans are highly dissatisfied with candidates running for mayor, and they are substantially more critical of the integrity of local elections than voters in the other two cities, especially regarding intimidation, vote-buying, and the inadequacy of the Electoral Commission.

As for its history, East Borneo's colonial political economy presents similarities with that of East Sumatra, as it was as reliant on imported foreign labour and natural resource extraction (Lindblad 1989). However, ethnic relations in Samarinda’s highly diverse population have been largely peaceful, especially when compared with neighbouring provinces (De Jonge and Nooteboom 2006). Its political leaders have also emphasised the importance of inter-ethnic cooperation (Aspinall 2011, 304). Furthermore, in contrast with East Sumatra, colonial authorities in Samarinda allowed higher degrees of civic and political freedoms than in many other regions in Kalimantan and Indonesia (Magenda 2010, 53). 
While historical factors loom large in shaping contemporary patterns of political competition and accountability, it would be a mistake to treat political life in these three cities as being historically determined. In fact, despite different historical trajectories, the three field sites present important similarities. First, all incumbent mayors were seeking re-election after serving a first, five-year term. While the accountability mechanism posited in the retrospective voting model might be impaired when re-election is not a viable prospect (for instance, because of institutional limits to the number of consecutive terms), we compare three cases in which incumbents were indeed seeking a second term in office. Second, pilkada elections in the three cities display low levels of electoral competitiveness, as the incumbent mayor won with $71.7 \%$ of the vote in Medan, $75.4 \%$ in Samarinda, and $86.2 \%$ in Surabaya. By choosing three electoral races dominated by incumbent politicians, the research design controls for the competitiveness of local politics, an institutional factor that may be closely related with patterns of retrospective voting. Third, political parties do not appear to play a prominent role in local elections in these three cities. According to our survey data, only about 5.2\% of respondents, with little variation across city, reported choosing what candidate to vote for based on the political parties that constituted the candidate's supporting coalition. Finally, these three elections do not appear to be influenced by national issues or politics in any significant respect. Although no systematic data were collected, electoral campaigns were dominated by local issues such as infrastructure development and social programmes, and almost no respondent in the three surveys (1.7\% on average) identifies the national government as being primarily responsible for the condition of their city.

Comparing these three elections allows an investigation of the relationship between local institutions and local-election voting behaviour. Given the variation in local politics and 
institutions described above, we expected retrospective voting behaviour to be weakest in Medan and stronger in Samarinda and Surabaya.

\section{DATA AND MODELS}

The three original surveys analysed in this paper were implemented with face-to-face interviews on representative samples of the populations of Medan, Samarinda, and Surabaya shortly after pilkada elections took place on December 9, 2015. Structured interviews were carried out through in-person field visits in the sampled households by a team of enumerators trained and co-ordinated by Lembaga Survei Indonesia, a leading social research institute. The sampling approach was based on a multi-stage random sampling strategy in which villages are the primary sample unit (PSU). ${ }^{3}$ Before sampling, the population of each city was stratified based on population at the sub-district level to obtain proportional samples in each of the subdistricts. It was then stratified further based on place of residence (urban/rural) and on gender to have an equal number of female and male respondents. After stratification, 41 PSUs in each city were selected through systematic random sampling, and five neighbourhood organisations (rukun tetangga or RT) for each PSU, two households for each RT, and one respondent for each

${ }^{3}$ Indonesian districts and cities are divided into sub-districts called kecamatan. Each sub-district, in turn, is divided into villages called desa when located in rural areas and kelurahan in urban areas. Finally, in each village, government-established neighborhood organisations (rukun tetangga) are the lowest administrative level in government. 
household were further selected at random. As a result, ten respondents were selected from each PSU, for a total of 410 respondents in each city.

To gauge the extent of retrospective voting in each city, we estimate logistic models in which the response variable is a binary indicator of self-reported vote for the incumbent mayor in municipal elections. Respondents who reported voting in mayoral election where asked which of the two candidates they voted for, and a total of 923 of them, or about $75 \%$ of the sample, answered this question. The verified turnout rates reported in Table 1, however, are much lower than those estimated with the samples in the three surveys (70.2\% for the survey implemented in Medan, 93.2\% in Samarinda, and $92.9 \%$ in Surabaya). Furthermore, electoral support for the incumbent appears to be higher in the survey samples than in validated electoral returns, as 86.7\% for respondents in Medan, 88.3\% in Samarinda, and 95.6\% in Surabaya reported voting for the incumbent mayor. This suggests that survey respondents have over-reported voting and incumbent support, a phenomenon that is a well-known limitation of survey data. ${ }^{4}$ Due to fieldwork constraints, however, validation of self-reported turnout data with alternative sources was not possible, and the analysis thus relies on survey indicators alone. This might be a source of bias if the factors related to over-reporting were also linked to the evaluations of local government performance. Nevertheless, given the paucity of scholarly work on voting overreporting in young democracies, the extent, direction, and even existence of this hypothetical

${ }^{4}$ The literature on advanced democracies has attributed over-reported to the social desirability of voting, and it has shown that over-reporting is not random, as it is related to both individual-level and contextual variables (see Bernstein, Chadha, and Montjoy 2001; Karp and Brockington 2005). 
bias are hard to ascertain. We thus maintain that the bias due to over-reporting, if at all present, is not substantial enough to compromise the findings presented.

In the estimated logistic models, voting for the incumbent mayor is a function of evaluations of local government performance and a host of covariates that may be related to local-election retrospective voting. To measure perceptions of local government performance, the survey asked respondents to evaluate overall local government performance along a five-point scale ranging from 1 (very bad) to 5 (very good). As shown in Table 1, there is substantial variation in average evaluations across the three field sites, with negative evaluations prevailing in Medan and positive evaluations prevalent in the other two cities. To address endogeneity concerns, all estimated models control for three factors that are known to affect support for the incumbent and perceptions of local government performance, namely evaluations of the national economy, evaluations of own household's economic condition, and partisanship. Model specification further controls for a range of demographic factors that might be related to voting behaviour, such as age, gender, ethnicity, religion, education, income, and occupational status. ${ }^{5}$ Finally, to account for possible clustering in the data due to the sampling design, models are estimated with PSU (village) cluster-robust standard errors.

We test the hypotheses on individual heterogeneity in retrospective voting by estimating a series of interactive logistic models with pooled data from the three city surveys and fixed effects for cities. In each model, the measure of perceived local government performance is interacted

${ }^{5}$ We provide in the Appendix more detailed information on how these variables are operationalised, and we include a table with descriptive statistics in each survey (see also Fossati 2016b). 
with one of various indicators tracking political knowledge, trust in local institutions, and responsibility attribution. To gauge political knowledge and interest, we employ two measures. First, the survey asks respondents a battery of ten questions on local politics, ranging from simple ones such as mentioning one of the candidates running for mayor to more difficult questions such as those pertaining to the role of local legislative councils. ${ }^{6}$ We use answers to these questions to build a simple additive index of political knowledge, counting the number of right answers for each respondent. As displayed in Table 1, the average number of correct answers is 4.8 in Medan, 6.5 in Samarinda, and 5.8 in Surabaya, which shows variation in political information across city. Second, as an additional indicator of political knowledge and interest, we use a question in which respondents are asked whether they feel they have gathered sufficient information during the electoral campaign before the elections. We build a dummy variable coded as 1 for respondents who reported getting enough or more than enough information, and 0 for those who felt the information they gathered was insufficient. Again, variation across survey is significant: while only $29.7 \%$ of respondents answer this question affirmatively in Medan, the percentage increases to 57.1\% in Surabaya and 51.1\% in Samarinda.

As for trust in political institutions, the first survey question we rely upon is a simple yes/no question that asks whether the respondent believe that local elections are free and fair. Most respondents in the sample, $89.5 \%$, answer this question affirmatively, although there is variation across survey (93.9\% answer affirmatively in Surabaya, 81.5\% in Medan, and 93.1\% in

\footnotetext{
${ }^{6}$ A list of the ten questions is included in the Appendix. In building the items for this scale, we conceptualise political knowledge as a one-dimension theoretical construct, following a wellestablished convention in the literature (Carpini and Keeter 1993).
} 
Samarinda). To assess if results are robust to different measures of perceptions of the integrity of local electoral institutions, we exploit a multiple-choice question in the survey asking respondents to identify areas of concern in local politics in their own city. Three of the choices listed for this question are closely related to the electoral process, as respondents are asked to report if they believe that voter intimidation, vote-buying, and ineffectiveness of the Electoral Commission (Komisi Pemilihan Umum or KPU) are a problem in local elections in their city. We build three binary indicators to track reporting of each of these factors, using them to estimate logistic models in which evaluations of local government performance are interacted with dichotomous variables.

Finally, to harness the process through which voters attribute responsibility for significant outcomes, the survey asks respondents to indicate what level of government (local, provincial or national) they believe is most responsible for the condition of their city and their own household. The answers to these questions display little variation across survey, and they show that most people consider local government to be the most responsible level of government for the condition of their city (87.7\%) and their household (75.8\%). We build binary indicators from these two questions and we interact them with evaluations of local government performance to test if responsibility attribution shapes local-election retrospective voting.

\section{ANALYSIS}

Table 2 reports logistic regression results for a basic model of retrospective voting, and it displays substantial variation across the three cities. The first column shows results with the data of the survey implemented in Medan, and it estimates the coefficient of performance evaluations 
at .212 with a p-value of .455 , suggesting that the relationship between evaluations of local government performance and voting behaviour is not significant at conventional statistical levels in this city. The results for Medan contrast with those for Samarinda and Surabaya, where the estimated coefficient for performance evaluations is much larger (.723 and .897, respectively) and statistically significant. To appreciate the implications of these results, consider the difference in estimated support for the incumbent mayor between two voters, the first evaluating local government performance as "bad” and the second as “good.” In Medan, the difference between the two is rather small, since the latter voter is only $5 \%$ more likely to support the incumbent than former. However, the difference is much more significant in the other two cities, as respondents evaluating local government performance as “good” are 19\% more likely to support the incumbent in Samarinda and 13\% in Surabaya. This suggests that, as hypothesised, variation in retrospective voting behaviour across the three cities is substantial.

\section{INSERT TABLE 2 ABOUT HERE}

Figure 1 represents differences across the three sites by juxtaposing three plots of estimated support for the incumbent at different levels of perceived local government performance. The left panel of the figure, reporting the chart for Medan, stands in sharp contrast with the other two. While the estimated probability lines in Samarinda and Surabaya show a strong link with perceived local government performance, the line in the left panel suggests a substantially weaker relationship. The model estimated with data from Medan thus suggests that, when compared with the other two cities, the estimated probability of incumbent support varies little across the values of local government performance. Furthermore, variation across the scale of 
local government evaluations is larger in Samarinda than in Surabaya, possibly because of the exceptionally high levels of support for the incumbent mayor in Surabaya, who won the elections with a commanding $86.2 \%$ of the vote. Overall, the results corroborate the hypothesis of substantial variation across city in the incidence of retrospective voting behaviour, which suggests that institutional factors are a prominent driver of voting behaviour in Indonesian local elections.

\section{INSERT FIGURE 1 ABOUT HERE}

Table 2 also invites some considerations on the other variables estimated by the model. First, evaluations of national and household economic conditions do not have a significant effect on voting behaviour. This finding is consistent with the assumption that pilkada elections are not significantly nationalised, as their outcomes are mostly determined by local factors. Second, and related to this, partisanship also appears to be playing a marginal role, as supporters of political parties in the winning coalition of the incumbent mayor are as likely to vote for the incumbent as voters with different party preferences. Again, this finding is consistent with a vast literature that portrays political parties as minor actors in pilkada elections. Finally, the effect of some of the estimated factors varies significantly across city. For instance, gender is a strong predictor of incumbent vote in Surabaya, a city where the mayor is a woman, but not in the other two sites. In Medan, there is a sharp religious cleavage in voting behaviour, as Muslim respondents are about $25 \%$ more likely to support the incumbent than non-Muslims, but no similar ethnic or religious 
cleavage is found in Samarinda or Surabaya. ${ }^{7}$ This suggests that local contextual factors are crucial determinants of electoral outcomes, and that the weight of identity-related factors in orienting voting choices varies substantially across municipality.

\section{INSERT TABLE 3 ABOUT HERE}

Table 3 reports estimation results for various multiplicative models in which evaluations for local government performance are interacted with measures of information on local politics, trust in local institutions and attribution of responsibility. The first two columns focus on the role of information, testing if, and to what extent, retrospective voting behaviour is more prominent in political sophisticates. To validate this hypothesis, Model 1 is estimated with an interaction term featuring an index of knowledge on local politics built from the ten questions asked to survey respondents, while Model 2 relies on a blunter, self-reported binary indicator of the amount of information acquired during the electoral campaign. While not significant at conventional levels, both interaction terms are signed as hypothesised, and the p-value for the interaction between evaluations and political knowledge is close to the .05 threshold. This suggests that political

${ }^{7}$ While both candidates in Medan were Muslim, the challenger’s campaign especially targeted non-Muslim voters for support. For instance, to appeal to the large Chinese community, an ethnic Chinese businessman was chosen as candidate vice-mayor. As for Samarinda and Surabaya, the coefficients for the variable "Muslim" could not be estimated in our models due to the low number of non-Muslim voters in these two cities, and they are therefore omitted from Table 2. 
sophistication, to a certain extent, is a moderating variable in the relationship between perceived local government performance and incumbent vote, a finding that resonates with results reported in the comparative literature on voting behaviour. While for low levels of information (that is, respondents who answered less than six questions correctly) the effect of local government performance on support for the incumbent is negligible, the effect is positive and significant for better-informed voters. ${ }^{8}$ Figure 2 plots this relationship with charts of estimated probabilities of support for the incumbent mayor at different levels of political sophistication, showing that support for the incumbent is positively associated with local government evaluations only in voters with at least average levels of information on local politics. ${ }^{9}$

\section{INSERT FIGURE 2 ABOUT HERE}

Models 3 to 6 estimate interactions between evaluations of local government and various measures of trust in local electoral institutions. ${ }^{10}$ Model 3 uses a binary indicator that tracks whether respondents believe local elections to be free and fair, and it estimates the coefficient of the multiplicative term at -1.24 with a p-value lower than .05 , suggesting that retrospective

${ }^{8}$ The magnitude of the effect ranges from $4 \%$ for respondents answering six of the ten questions correctly to $5.9 \%$ for the few who did not make any mistakes.

${ }^{9}$ The number of questions answered correctly varies from three in the left panel to six in the centre and eight in the right panel.

${ }^{10}$ In all dummy variables used in these four models, a value of 1 indicates distrust in local elections. The expectation is thus that all interactive models are signed negatively. 
voting is less likely in voters who do not trust the integrity of local elections. ${ }^{11}$ Similar results are reported for Model 4, which tests the hypothesis that voters who perceive local elections as being marred by intimidation are less likely to vote retrospectively. However, in Models 5 and 6, which use binary indicators to track, respectively, perceptions of vote-buying and Electoral Commission effectiveness, interaction terms are of modest magnitude and not statistically significant at conventional levels. The four models thus find mixed empirical support for the hypothesised relationship between trust in electoral institutions and voting behaviour. On one hand, as suggested by the comparative research reviewed earlier, there is evidence that perceptions of integrity and fairness shape retrospective voting, and that their effect is comparable in size to that estimated for political knowledge. On the other hand, the results are sensitive to the indicators used, which suggests that some aspects of the electoral process, such as voter fraud and violence, might be more salient for voters than others, such as vote-buying and the impartiality of the local Electoral Commission.

Finally, Models 7 and 8 focus on the process of responsibility attribution by interacting two binary indicators of responsibility attribution with evaluations of local government performance. Model 7 employs a dummy variable based on the survey question that asks respondents if they consider local government responsible for the condition of their city. The model estimates the interactive term at 1.23, associated with a p-value of .045. This indicates an important effect of

${ }^{11}$ For voters who believe local election are free and fair, a one-point increase in evaluation of local government performance increases estimated support for the incumbent of about 3.5\%, but evaluations do not affect support for the incumbent in voters who do not believe in the integrity of local elections. 
responsibility attribution on retrospective voting, a result that is consistent with research on voting behaviour in other multi-level political systems. ${ }^{12}$ However, results from Model 8 suggests that the effect of the attributional process is contingent on the specific outcome that is being attributed. When using the indicator that asks if respondents consider local government responsible for the situation of their household, the estimated interaction term is much smaller in magnitude (-.012) and not statistically significant at conventional levels. Figure 3 summarises the results of the analysis by reporting plots of marginal effects of local government evaluations at different levels of the interaction terms used in the eight models estimated in Table 3.

\section{INSERT FIGURE 3 ABOUT HERE}

\section{CONCLUSIONS}

In decentralised young democracies, local politics is a key determinant of policy outcomes. This article has explored democratic accountability in Indonesian local elections by focusing on ordinary voters and it has argued that voting behaviour is strongly associated with the sub-

${ }^{12}$ Respondents who hold local government responsible for the condition of their city show higher estimated support for the incumbent at higher levels of local government performance evaluations, as predicted probabilities increase from .73 for "very bad" evaluations to .90 for “very good”. By contrast, in voters who believe local government is not the level of government most responsible for the condition of their city, predicted support for the incumbent does not increase at higher levels of perceived local government performance. 
national institutional differences typically observed in diverse, decentralised low and middleincome countries such as Indonesia. The results further suggest that political knowledge, trust in local electoral institutions and the process of responsibility attribution are important factors in moderating the relationship between perceived local government performance and support for incumbent politicians.

Before discussing the importance of these findings for understanding of local politics in Indonesia and beyond, we should emphasise that the analysis performed here is not without limitations. First, the survey data analysed suffer from some important drawbacks. As discussed above, self-reported voting has not been validated with alternative sources, and there is evidence of over-reporting among survey respondents. Furthermore, in two of the three field sites, positive evaluations of local government largely prevail, and the estimates for lower local government performance scores thus rely on a limited number of observations. Second, all three elections were dominated by incumbent politicians. While we have presented this as an advantage of our empirical approach, it is also a limitation, in that this research design does not allow the study of the role of electoral competitiveness, which is an important factor in shaping citizen-politician linkages (Weitz-Shapiro 2012). Finally, the measure of perceived local government performance is plausibly endogenous to various factors, such as partisanship, evaluations of households and national economic conditions, political endorsements, and so forth. As discussed, we control for several of these factors in quantitative analysis with a range of accurate indicators built from survey data, but we are unable to fully overcome the limitations of observational data.

Despite these shortcomings, our results have important implications for how scholars conceptualise and study local politics in Indonesia. In some respects, our analysis corroborates findings emerging from the qualitative literature. As expected, the data indicate that sub-national 
variation in citizen-politician linkages is substantial, political parties do not play a large role in local-election voting behaviour and electoral outcomes are largely the result of local rather national political dynamics. However, our main findings suggest that a divergence is emerging between how the literature portrays popular participation in local politics and how many Indonesians understand and experience electoral campaigns and participation in local elections.

Most scholarly work on Indonesian local politics studies patterns of political competition in regions through the lenses of clientelism and elite politics. From this perspective, it is easy to find empirical evidence suggesting that patronage and oligarchic interests are the main drivers of politics and that popular agency is a marginal factor. We have questioned these conclusions by adopting a different methodological approach from those prevailing in existing research, and, in so doing, we have uncovered dynamics of popular participation that were previously left unexplored. When we switch our analytical focus from political elites to voters, we find that retrospective reasoning is an important determinant of local-election voting behaviour. The data we have analysed thus indicate that local politics is not exclusively transactional, and that there is more to local elections than patronage relationships, clashes among powerful interest groups and political parties colluding to stifle genuine accountability. Many of the citizens we have interviewed in Medan, Samarinda and Surabaya spend time acquiring information on politicians and evaluating their performance as local leaders. And when they vote, they often vote to reward or punish incumbents for what they do in office.

To be sure, some important conditions must be met for citizens to hold politicians accountable for their performance, and such prerequisites are sometimes missing in Indonesia. Yet again, this qualification applies to participation and voting behaviour in more established democracies as well. The comparative literature we have reviewed in previous sections shows 
that dynamics of accountability vary substantially both across countries and across individuals. Our three surveys suggest that Indonesia conforms to these expectations, as we have documented substantial variation in voting behaviour across the three cities and the hundreds of individuals interviewed. Furthermore, we have found that such variations are consistent with theoretical expectations from the comparative literature about the role of information, trust in electoral integrity, and the process of responsibility attribution. In comparative perspective, local politics in Indonesia thus displays more similarities with than differences from local politics elsewhere. Although there is clear evidence that accountability between voters and politicians may be broken in some cases, we also find evidence of an emerging process through which, in the medium term, local democracy in Indonesia may consolidate and deepen.

The degree to which these implications apply to local politics anywhere in this vast and diverse archipelago is of course debatable. The recent case of gubernatorial elections in Jakarta in April 2017, for instance, provides an interesting counterpoint to the theory we propose. After an intense electoral campaign marked by inflammatory religious rhetoric, the incumbent governor, a Christian Chinese, lost to an opponent backed by a coalition comprising radical Islamists that were previously relegated to the fringes of Indonesian politics. Interestingly, survey data show that the incumbent Basuki Tjahaja Purnama lost the elections despite a vast majority of Jakartans were satisfied with his performance as a governor (see Mietzner and Muhtadi 2017). Religious identities thus appear to have trumped democratic accountability mechanisms, exposing the vulnerability of Indonesian democracy to illiberal forces and raising concerns about religious sectarianism. However, generalising from the Jakarta case is arguably even more problematic than extrapolating from our three surveys. The Jakarta gubernatorial race is unlike any other local election in Indonesia, as it constitutes a high-profile political event 
fraught with implications for national politics. Moreover, the case of an ethnic Chinese vying for such a prominent position is unprecedented in a country where anti-Sinicism runs deep. It is therefore difficult to infer about broader trends in Indonesian politics and society from this specific case.

Future research can complement the analysis presented here by addressing the methodological shortcomings of this study and by refining the theoretical framework we have articulated. For instance, validated voting data can increase the accuracy of the quantitative estimates, and comparative analysis across a larger number of cases could identify more precisely the specific role of various institutional features. Experimental research designs can further strengthen causal inference by introducing exogenous variation in factors that are known to orient voting choices and evaluations of incumbent politicians, such as information on local government performance or responsibilities. Finally, while we have presented retrospective voting as a form of accountability alternative to clientelist linkages, it is important to emphasise that the findings reported here do not rule out the possibility that the two are, in fact, related. A natural extension of this research is therefore to investigate more systematically the sources for public perceptions of local government performance, focusing on how patronage spending, ethnic politics and partisan identities influence and in turn are influenced by how people evaluate the performance of local politicians. 


\section{ACKNOWLEDGEMENTS}

I am deeply grateful to ISEAS-Yusof Ishak Institute for generously funding data collection for this project. Several colleagues have contributed to this paper: Ulla Fionna, Hui Yew-Foong and Deasy Simandjuntak have provided valuable input for questionnaire design; Ward Berenschot has graciously shared data on clientelism; Ferran Martinez i Coma, Mai Nguyen, Tom Pepinsky and four anonymous reviewers have given insightful comments. I am responsible for any errors. 


\section{REFERENCES}

Anderson, B. 1972. Java in a Time of Revolution. Ithaca: Cornell University Press.

Anderson, C. D. 2006. "Economic Voting and Multilevel Governance: A Comparative Individual-Level Analysis." American Journal of Political Science 50 (2):449-463.

Anderson, C. J. 2007. "The End of Economic Voting? Contingency Dilemmas and the Limits of Democratic Accountability." Annual Review of Political Science 10:271-296.

Aspinall, E. 2011. "Democratization and Ethnic Politics in Indonesia: Nine Theses." Journal of East Asian Studies 11 (02):289-319.

Aspinall, E. 2013. "Popular Agency and Interests in Indonesia's Democratic Transition and Consolidation." Indonesia 96 (1):101-121.

Aspinall, E., S. Dettman, and E. Warburton. 2011. "When Religion Trumps Ethnicity: A Regional Election Case Study from Indonesia." South East Asia Research 19 (1):27-58.

Aspinall, E., N. Rohman, A. Z. Hamdi, and Z. E. Triantini. 2017. "Vote Buying in Indonesia: Candidate Strategies, Market Logic and Effectiveness." Journal of East Asian Studies 17 (1):1-27.

Aspinall, E., and M. Sukmajati. 2016. Electoral Dynamics in Indonesia: Money Politics, Patronage and Clientelism at the Grassroots. Singapore: NUS Press.

Bardhan, P. 2002. "Decentralization of Governance and Development." Journal of Economic Perspectives 16 (4):185-205.

Berenschot, W. 2015. "The Political Economy of Clientelism: A Comparative Study of Indonesia’s Patronage Democracy." Unpublished manuscript.

Bernstein, R., A. Chadha, and R. Montjoy. 2001. "Overreporting Voting: Why It Happens and Why It Matters." Public Opinion Quarterly 65 (1):22-44. 
Berry, C. R., and W. G. Howell. 2007. "Accountability and Local Elections: Rethinking Retrospective Voting." Journal of Politics 69 (3):844-858.

Birch, S. 2010. "Perceptions of Electoral Fairness and Voter Turnout." Comparative Political Studies 43 (12):1601-1622.

Buehler, M. 2010. "Decentralisation and Local Democracy in Indonesia: The Marginalisation of the Public Sphere." In Problems of Democratisation in Indonesia: Elections, Institutions and Society, edited by Edward Aspinall and Marcus Mietzner, 267-285. Singapore: ISEAS.

Buehler, M. 2013. "Married with Children." Inside Indonesia 112.

Bunnell, T., M. A. Miller, N. A. Phelps, and J. Taylor. 2013. "Urban Development in a Decentralized Indonesia: Two Success Stories?". Pacific Affairs 86 (4):857-876.

Carpini, M. X. D., and S. Keeter. 1993. "Measuring Political Knowledge: Putting First Things First." American Journal of Political Science 37 (4):1179-1206.

Choi, N. 2007. "Local Elections and Democracy in Indonesia: The Riau Archipelago." Journal of Contemporary Asia 37 (3):326-345.

Cutler, F. 2004. "Government Responsibility and Electoral Accountability in Federations." Publius: The Journal of Federalism 34 (2):19-38.

Cutler, F., and J. S. Matthews. 2005. "The Challenge of Municipal Voting: Vancouver 2002." Canadian Journal of Political Science 38 (02):359-382.

Davidson, J. S. 2007. "Politics-as-Usual on Trial: Regional Anti-Corruption Campaigns in Indonesia." The Pacific Review 20 (1):75-99.

De Jonge, H., and G. Nooteboom. 2006. "Why the Madurese? Ethnic Conflicts in West and East Kalimantan Compared." Asian Journal of Social Science 34 (3):456-474. 
Dick, H. W. 2003. Surabaya, City of Work: A Socioeconomic History, 19002000.

Singapore: NUS Press.

Duch, R. M. 2001. "A Developmental Model of Heterogeneous Economic Voting in New Democracies." American Political Science Review 95 (4):895-910.

Duch, R. M., and R. T. Stevenson. 2008. The Economic Vote: How Political and Economic Institutions Condition Election Results. New York: Cambridge University Press.

Fossati, D. 2016a. "Is Indonesian Local Government Accountable to the Poor? Evidence from Health Policy Implementation." Journal of East Asian Studies 16 (3):307-330.

Fossati, D. 2016b. The State of Local Politics in Indonesia: Survey Evidence from Three Cities. Vol. 2016, Trends in Southeast Asia. Singapore: ISEAS.

Fossati, D. 2017. "From Periphery to Centre: Local Government and the Emergence of Universal Healthcare in Indonesia." Contemporary Southeast Asia 39 (1):178-203.

Furnivall, J. S. 2010. Netherlands India: A Study of Plural Economy: Cambridge University Press.

Gomez, B. T., and J. M. Wilson. 2001. "Political Sophistication and Economic Voting in the American Electorate: A Theory of Heterogeneous Attribution." American Journal of Political Science 45 (4):899-914.

Hadiz, V. R. 2004a. "Decentralization and Democracy in Indonesia: A Critique of NeoInstitutionalist Perspectives." Development and Change 35 (4):697-718.

Hadiz, V. R. 2004b. "Indonesian Local Party Politics: A Site of Resistance to Neoliberal Reform." Critical Asian Studies 36 (4):615-636. 
Hadiz, V. R. 2006. "Corruption and Neo-Liberal Reform: Markets and Predatory Power in Indonesia and Southeast Asia." In The Neo-Liberal Revolution: Forging the Market State, edited by Richard Robison, 79-97. London: Palgrave Macmillan UK.

Hadiz, V. R. 2010. Localising Power in Post-Authoritarian Indonesia: A Southeast Asia Perspective. Stanford, CA: Stanford University Press.

Hadiz, V. R., and R. Robison. 2005. "Neo-Liberal Reforms and Illiberal Consolidations: The Indonesian Paradox." Journal of Development Studies 41 (2):220-241.

Healy, A., and N. Malhotra. 2013. "Retrospective Voting Reconsidered." Annual Review of Political Science 16:285-306.

Hopkins, D. J., and L. M. Pettingill. 2015. "Economic Voting in Big-City Us Mayoral Elections." Available at SSRN 2567294.

Howell, S. E., and H. L. Perry. 2004. "Black Mayors/White Mayors: Explaining Their Approval." Public Opinion Quarterly 68 (1):32-56.

Ilmma, A., and M. Wai-Poi. 2014. "Patterns of Regional Poverty in the New Indonesia." In Regional Dynamics in a Decentralized Indonesia, edited by Hal Hill, 98-134. Singapore: ISEAS.

Ingleson, J. 2008. "Sutomo, the Indonesian Study Club and Organised Labour in Late Colonial Surabaya." Journal of Southeast Asian Studies 39 (01):31-57.

Karp, J. A., and D. Brockington. 2005. "Social Desirability and Response Validity: A Comparative Analysis of Overreporting Voter Turnout in Five Countries." Journal of Politics 67 (3):825-840.

Kaufmann, K. M. 2004. The Urban Voter. Ann Arbor: University of Michigan Press. 
Kaufmann, K. M., and A. Rodriguez. 2011. "Political Behavior in the Context of Racial Diversity: The Case for Studying Local Politics." PS: Political Science \& Politics 44 (01):101102.

Keefer, P. 2007. "Clientelism, Credibility, and the Policy Choices of Young Democracies." American Journal of Political Science 51 (4):804-821.

Keefer, P., and S. Khemani. 2005. "Democracy, Public Expenditures, and the Poor: Understanding Political Incentives for Providing Public Services." World Bank Research Observer 20 (1):1-27.

Leisher, S. H., and S. Nachuk. 2006. Making Services Work for the Poor: A Synthesis of Nine Case Studies from Indonesia. Jakarta: World Bank.

Leon, S. 2011. "Who Is Responsible for What? Clarity of Responsibilities in Multilevel States: The Case of Spain." European Journal of Political Research 50 (1):80-109.

Lewis, B., N. McCulloch, and A. Sacks. 2014. What Drives Local Service Delivery Performance in Indonesia, Department of Foreign Affairs and Trade Working Papers. Jakarta: Australian Aid.

Lewis, B. D. 2014. "Twelve Years of Fiscal Decentralization: A Balance Sheet." In Regional Dynamics in a Decentralized Indonesia, edited by Hal Hill, 135-155. Singapore: ISEAS.

Lindblad, J. T. 1989. "Economic Aspects of the Dutch Expansion in Indonesia, 1870-1914." Modern Asian Studies 23 (01):1-24.

LSI. 2014. "Pro-Kontra Pilkada Langsung." Jakarta: Lembaga Survei Indonesia.

Magenda, B. D. 2010. East Kalimantan: The Decline of a Commercial Aristocracy. Sheffield, UK: Equinox Publishing. 
Martinez i Coma, F., and M. Trinh. 2017. "How Electoral Integrity Affects Voter Turnout in Democracies." Australian Journal of Political Science 52 (1):53-74.

Mietzner, M. 2009. "Indonesia and the Pitfalls of Low-Quality Democracy: A Case Study of the Gubernatorial Elections in North Sulawesi." In Democratization in Post-Suharto Indonesia, edited by Marco Bunte and Andreas Ufen, 124-148. New York: Routledge.

Mietzner, M. 2011. "Funding Pilkada: Illegal Campaign Financing in Indonesia's Local Elections." In The State and Illegality in Indonesia, edited by Edward Aspinall and Gerry Van Klinken, 123-138. Leiden: KITLV Press.

Mietzner, M. 2013. "Fighting the Hellhounds: Pro-Democracy Activists and Party Politics in Post-Suharto Indonesia." Journal of Contemporary Asia 43 (1):28-50.

Mietzner, M., and B. Muhtadi. 2017. "Ahok’s Satisfied Non-Voters: An Anatomy." In New Mandala.

Oates, W. E. 1999. "An Essay on Fiscal Federalism." Journal of Economic Literature 37 (3):1120-1149.

Oliver, J. E., and S. E. Ha. 2007. "Vote Choice in Suburban Elections." American Political Science Review 101 (03):393-408.

Pepinsky, T. B., and M. M. Wihardja. 2011. "Decentralization and Economic Performance in Indonesia." Journal of East Asian Studies 11 (3):337-371.

Powell, G. B., and G. D. Whitten. 1993. "A Cross-National Analysis of Economic Voting: Taking Account of the Political Context." American Journal of Political Science 37 (2):391-414. Reid, A. 2014. The Blood of the People: Revolution and the End of Traditional Rule in Northern Sumatra. Singapore: NUS Press. 
Rosser, A., and I. Wilson. 2012. "Democratic Decentralisation and Pro-Poor Policy Reform in Indonesia: The Politics of Health Insurance for the Poor in Jembrana and Tabanan." Asian Journal of Social Science 40 (5-6):608-634.

Schulze, G. G., and B. S. Sjahrir. 2014. "Decentralization, Governance and Public Service Delivery." In Regional Dynamics in a Decentralized Indonesia, edited by Hal Hill, 186-207. Singapore: ISEAS.

Seymour, R., and S. Turner. 2002. "Otonomi Daerah: Indonesia's Decentralisation Experiment." New Zealand Journal of Asian Studies 4 (2):33-51.

Simandjuntak, D. 2012. "Gifts and Promises: Patronage Democracy in a Decentralised Indonesia." European Journal of East Asian Studies 11 (1):99-126.

Simanjuntak, F., and A. R. Akbarsyah. 2008. Measuring Corruption in Indonesia: Indonesia Corruption Perception Index 2008 and Bribery Index. Jakarta: Transparency International Indonesia.

Simpser, A. 2012. "Does Electoral Manipulation Discourage Voter Turnout? Evidence from Mexico." The Journal of Politics 74 (03):782-795.

Slater, D. 2004. "Indonesia's Accountability Trap: Party Cartels and Presidential Power after Democratic Transition." Indonesia (78):61-92.

Sumarto, S., M. Vothknecht, and L. Wijaya. 2014. "Explaining Regional Heterogeneity of Poverty: Evidence from a Decentralized Indonesia." In Regional Dynamics in a Decentralized Indonesia, edited by Hal Hill, 68-97. Singapore: ISEAS.

Svolik, M. W. 2013. "Learning to Love Democracy: Electoral Accountability and the Success of Democracy." American Journal of Political Science 57 (3):685-702. 
Tans, R. 2012. Mobilizing Resources, Building Coalitions: Local Power in Indonesia, Policy Studies. Honolulu, HI: East-West Center.

Tiebout, C. M. 1956. "A Pure Theory of Local Expenditures." Journal of Political Economy 64 (5):416-424.

Van Klinken, G. 2009. "Patronage Democracy in Provincial Indonesia." In Rethinking Popular Representation, edited by Olle; Törnquist, Neil; Webster and Kristian Stokke, 141159. New York: Palgrave Macmillan.

Von Luebke, C., N. McCulloch, and A. A. Patunru. 2009. "Heterodox Reform Symbioses: The Political Economy of Investment Climate Reforms in Solo, Indonesia." Asian Economic Journal 23 (3):269-296.

Weitz-Shapiro, R. 2012. "What Wins Votes: Why Some Politicians Opt out of Clientelism." American Journal of Political Science 56 (3):568-583. 


\section{APPENDIX}

\section{Variable operationalisation and coding}

\begin{tabular}{lll}
\hline Variable & Survey question & Coding \\
\hline Voted for the incumbent & $\begin{array}{l}\text { Who did you vote for, among these pairs of } \\
\text { candidates? }\end{array}$ & $\begin{array}{l}\text { Binary variable. 1=voted for the incumbent; } \\
\text { 0=voted for the challenger. }\end{array}$ \\
$\begin{array}{l}\text { Evaluation of local } \\
\text { government }\end{array}$ & $\begin{array}{l}\text { In general, how do you evaluate the work of } \\
\text { city government? }\end{array}$ & $\begin{array}{l}\text { 5-point scale. 1=very bad; 2=bad; 3=average; } \\
\text { 4=good; 5=very good. }\end{array}$ \\
$\begin{array}{l}\text { Evaluation of national } \\
\text { economic conditions }\end{array}$ & $\begin{array}{l}\text { In general, how do you evaluate the economic } \\
\text { condition of the country right now? }\end{array}$ & $\begin{array}{l}\text { 5-point scale. 1=very bad; 2=bad; 3=average; } \\
\text { 4=good; 5=very good. }\end{array}$ \\
$\begin{array}{l}\text { Evaluation of household's } \\
\text { economic conditions }\end{array}$ & $\begin{array}{l}\text { In general, how do you evaluate the economic } \\
\text { condition of your household right now? }\end{array}$ & $\begin{array}{l}\text { 5-point scale. 1=very bad; 2=bad; 3=average; } \\
\text { 4=good; 5=very good. }\end{array}$ \\
$\begin{array}{l}\text { Supports incumbent's } \\
\text { party }\end{array}$ & $\begin{array}{l}\text { If there were (national) elections right now, } \\
\text { what political party would you vote for? }\end{array}$ & $\begin{array}{l}\text { Binary variable. 1=would vote for one of the } \\
\text { parties supporting the incumbent in local } \\
\text { elections; 0=would not vote for one of the parties } \\
\text { supporting the incumbent in local elections, or } \\
\text { the information is missing. Parties supporting the } \\
\text { incumbent mayor are as follows. Medan: PDI-P, } \\
\text { Golkar, PKS, PAN, PKPI, NasDem, PBB. } \\
\text { Samarinda: Demokrat, NasDem, PKS. Surabaya: } \\
\text { PDI-P. }\end{array}$
\end{tabular}

$\begin{array}{ll}\begin{array}{l}\text { Age } \\ \text { Sex }\end{array} & \begin{array}{l}\text { What is your age? } \\ \text { Coded by the interviewer } \\ \text { Javanese }\end{array} \\ \text { Besides being an Indonesian citizen, what } \\ \text { ethnic group do you belong to? }\end{array}$

Number of years.

Binary variable. 1 =female; $0=$ male.

Binary variable. $1=$ Javanese; $0=$ any other group.

Binary variable. $1=$ Muslim; $0=$ any other religion.

10-point scale. 1. Never went to school; 2. Didn't finish elementary school; 3 . Finished elementary school; 4. Didn't finish junior high school; 5. Finished junior high school; 6. Didn't finish senior high school; 7. Finished senior high school; 8. Didn't finish higher education/still studying;

9. Diploma; 10. College degree or higher.

Income

On average, what is the monthly income in your household, before taxes?

12-point scale (currency: IDR). 1. Less than 200K; 2. 200 to $399 \mathrm{~K}$; 3.400 to $599 \mathrm{~K}$; 4.600 to $799 \mathrm{~K} ; 5.800$ to $999 \mathrm{~K} ; 6.1$ to $1.199 \mathrm{M}$; 7. 1.2 to $1.399 \mathrm{M} ; 8.1 .4$ to $1.599 \mathrm{M}$; 9 . 1.6 to $1.799 \mathrm{M} ; 10$. 1.8 to $1.999 \mathrm{M} ; 11$. 2 to $4 \mathrm{M}$; 12 . More than $4 \mathrm{M}$. 
Political Knowledge Index

Ten questions on local politics:

1. Please name a candidate for mayor in the recent elections. 2. Who was his/her running mate? 3. Mention one political party supporting them. 4. How long is the office term for the mayor? 5. Can the mayor be deposed the local legislative council? 6 . Who is the governor of your province? 7. How long is the term in office for the governor? 8. Can the government be deposed by the provincial legislative council? 9 . What institution is in charge of passing local regulations? 10 . Who is [head of local legislative council]?

Acquired sufficient information

Local elections are not free and fair

Episodes of intimidation are a problem

Vote-buying is a problem

Local electoral commission is not doing its job

City government is responsible for condition of the city

City government is responsible for my household's condition
How much information did you acquire about the local election that has just taken place?

In your opinion, were the recent mayoral elections free and fair?

Based on your experience, what problems appear in mayoral elections in your city? (choose up to three)

Based on your experience, what problems appear in mayoral elections in your city? (choose up to three)

Based on your experience, what problems appear in mayoral elections in your city? (choose up to three)

In your opinion, in general, who is most responsible for the condition of your city?

In your opinion, in general, who is most responsible for the economic condition of your household?
Number of questions answered correctly. Missing answers are counted as incorrect.

Binary variable. 1=“Enough” or "A lot”; $0=$ "None" or "A little".

Binary variable. 1=“No"; 0="Yes”.

Binary variable. $1=$ "There is violence or threats (intimidation)" is mentioned; $0=$ it is not mentioned.

Binary variable. $1=$ "Money politics is rampant" is mentioned; $0=i t$ is not mentioned.

Binary variable. 1="The Local Electoral Commission is not performing its tasks well” is mentioned; $0=i t$ is not mentioned.

Binary variable. $1=$ "The city government”; $0=$ "The province government" or "The national government”.

Binary variable. 1=“The city government”; $0=$ "The province government" or "The national government”. 


\section{Descriptive statistics}

\begin{tabular}{lccccc}
\hline Variable & $N$ & Mean & SD & Min & Max \\
\hline Voted for the incumbent & 923 & 0.91 & 0.29 & 0 & 1 \\
Evaluation of local government & 1201 & 3.38 & 0.81 & 1 & 5 \\
Evaluation of national economic conditions & 1187 & 2.69 & 0.80 & 1 & 5 \\
Evaluation of household's economic conditions & 1223 & 3.05 & 0.72 & 1 & 5 \\
Supports incumbent's party & 923 & 0.36 & 0.48 & 0 & 1 \\
Age & 1228 & 43.19 & 13.29 & 17 & 90 \\
Sex & 1229 & 0.50 & 0.50 & 0 & 1 \\
Javanese & 1229 & 0.57 & 0.50 & 0 & 1 \\
Muslim & 1229 & 0.90 & 0.30 & 0 & 1 \\
Education & 1216 & 6.00 & 2.27 & 1 & 10 \\
Income & 1207 & 9.37 & 2.62 & 1 & 12 \\
Employed & 1229 & 0.61 & 0.49 & 0 & 1 \\
Political Knowledge Index & 1229 & 5.70 & 1.93 & 0 & 10 \\
Acquired sufficient information & 1224 & 0.46 & 0.50 & 0 & 1 \\
Local elections are not free and fair & 1229 & 0.10 & 0.31 & 0 & 1 \\
Episodes of intimidation are a problem & 1229 & 0.07 & 0.26 & 0 & 1 \\
Vote-buying is a problem & 1229 & 0.23 & 0.42 & 0 & 1 \\
Local electoral commission is not doing its job & 1229 & 0.09 & 0.29 & 0 & 1 \\
City government is responsible for condition of the city & 1183 & 0.88 & 0.33 & 0 & 1 \\
City government is responsible for my household's condition & 923 & 0.76 & 0.43 & 0 & 1
\end{tabular}



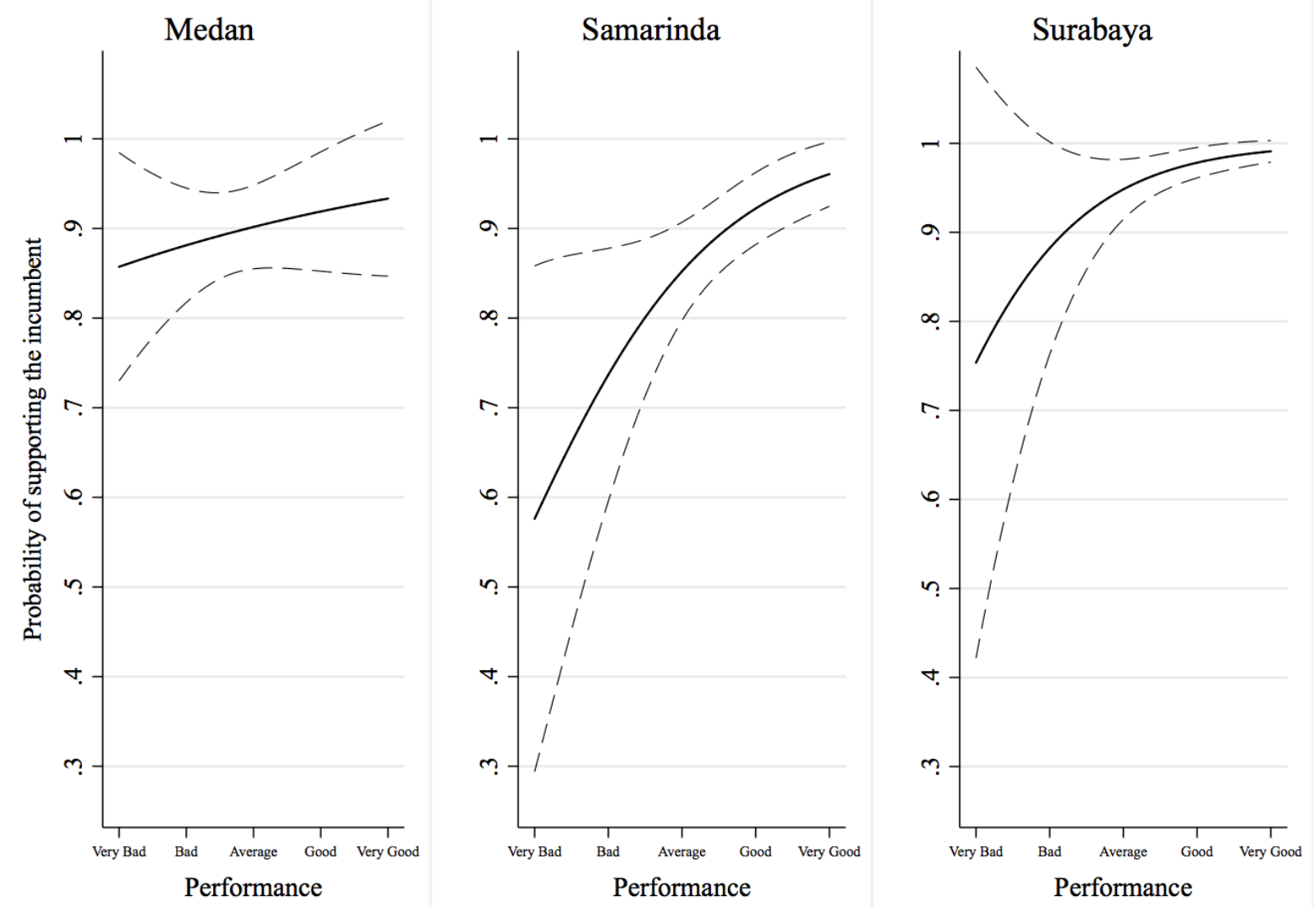

Figure 1 

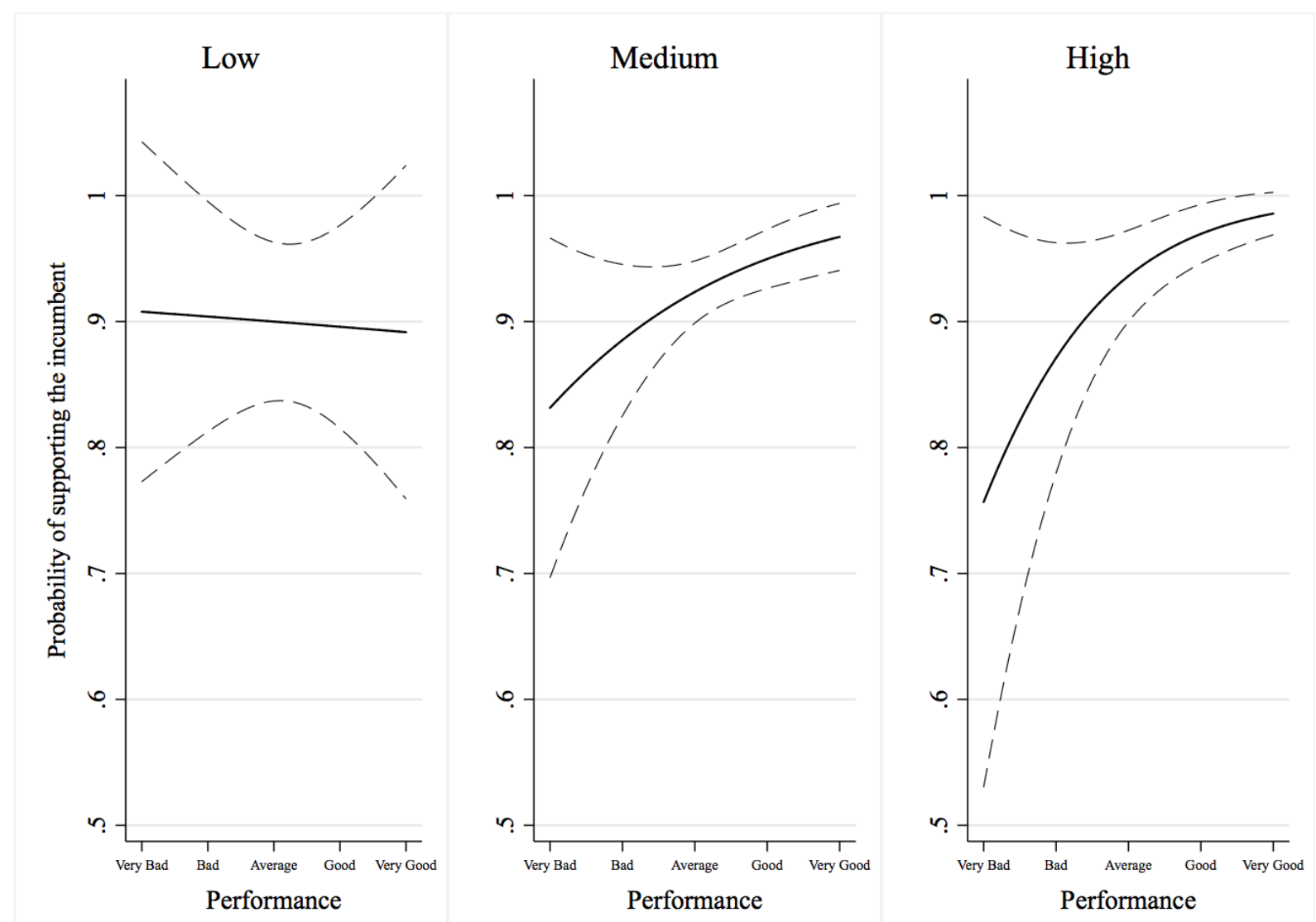

Figure 2 

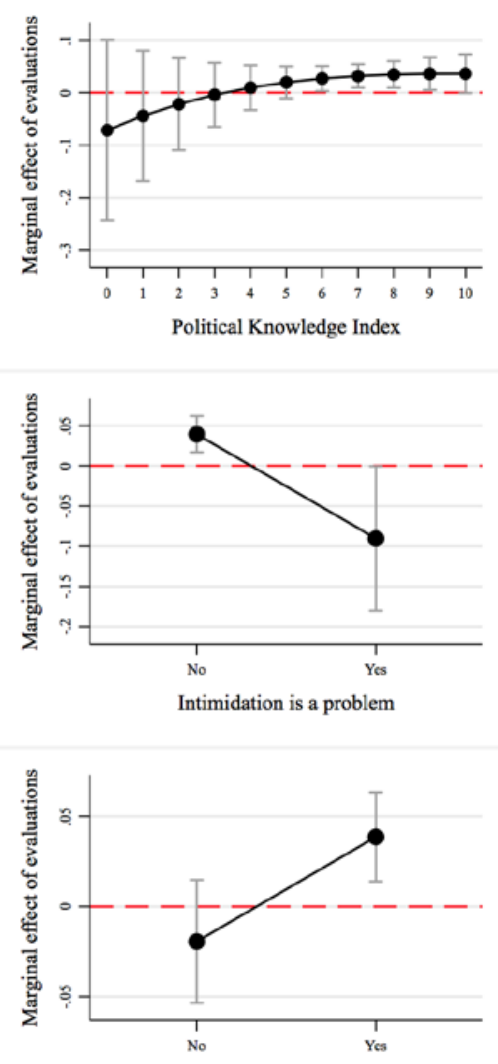

City government responsible
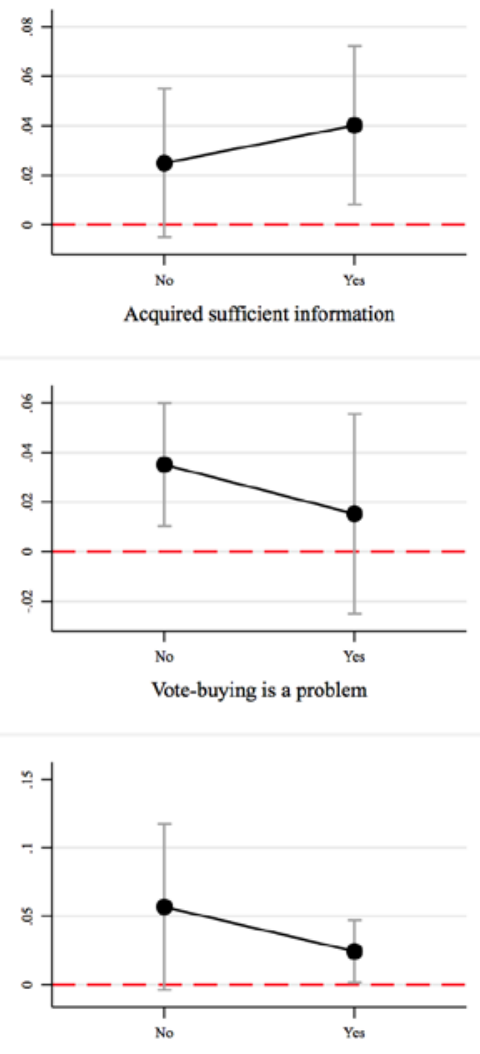

City government responsible (household)
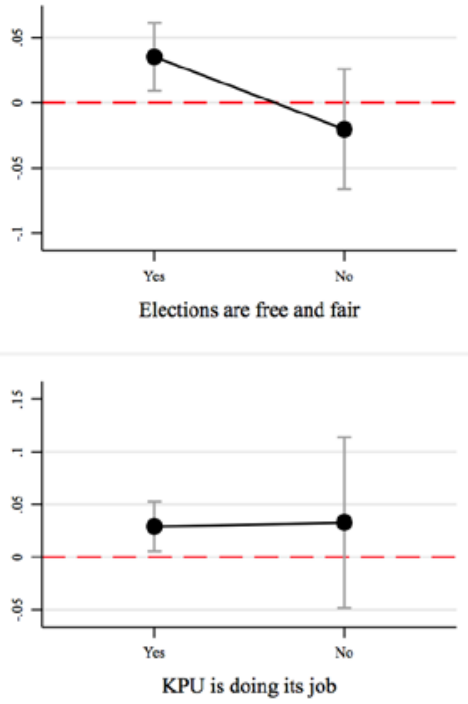

KPU is doing its job

Figure 3 